\title{
Ethnobotanical Identification and Anti-microbial Evaluation of Some Anti- Diarrhoreal Plants Used by the Samburu Community, Kenya
}

\author{
Eric Omwenga Omori ${ }^{1 *}$, Ogol Calistus ${ }^{2}$, Paul Kamau Mbugua ${ }^{3}$ and Paul Owour Okemo ${ }^{3}$ \\ ${ }^{1}$ Faculty of Health sciences, Kisii University College, P.O. Box 408 - 40200, Kisii, Kenya \\ ${ }^{2}$ Zoological sciences Department, Kenyatta University, P.O Box 43844- 00100, Nairobi Kenya. \\ ${ }^{3}$ Department of Plant and Microbial Sciences, Kenyatta University, P.O Box 43844, Nairobi 00100, Kenya \\ E-mail: omorieric@gmail.com
}

Received 14 March 2012; received in revised form 28 November 2011; accepted 11 January 2012

\begin{abstract}
Aims:The anti-bacterial effect of some selected Samburu medicinal plants were evaluated on bacterial strains like Staphylococcus aureus-ATCC 20591, Bacillus subtillis-local isolate, Salmonella typhi-ATCC 2202, Escherichia coli-STD25922 and Pseudomonas aeruginosa-ATCC 25852.

Methodology and Results: Methanol was used as an extraction solvent for the medicinal plants after they had been dried and ground using the laboratory grinding miller. The in vitro anti-bacterial activity was performed by agar disc diffusion method. The significant anti-microbial activity of active extracts was compared with the standard antibiotics, cefrodoxima and amoxicillin. These results were significant at $p<0.01$. The MICs were also determined by the micro titre-plate method. The MICs of the most active plants ranged from $18.75 \mathrm{mg} / \mathrm{mL}$ to $37.5 \mathrm{mg} / \mathrm{mL}$. The MBCs ranged between $18.75 \mathrm{mg} / \mathrm{mL}$ to $37.5 \mathrm{mg} / \mathrm{mL}$. The most active plant that had substantial activity in at least all the test cultures was found to be Lannea triphylla (A.Rich) Engl. A number of phytochemicals were also found to be present with tannins being the most abundant followed by flavonoids and saponins.

Conclusion, significance and impact of study: The findings show that most of the medicinal plants used by the Samburu community have some significant activity on the bacterial isolates known to cause diarrhoea.
\end{abstract}

Keywords: diarrhoea; medicinal plants; phytochemicals; antimicrobial activity; ethnobotany

\section{INTRODUCTION}

The Samburu community is one of those communities that are marginalized in Kenya in terms of 'HEALTH CARE FOR ALL' as a basic human right and prerequisite to social-economic development. The frequent use of medicinal plants by the Samburu for health care is because of the in availability of health care services from the government in this remote region of Kenya (Omwenga et al., 2009). It is estimated that about $85 \%$ of the Samburu community's medicare is from medicinal plants (Bussmann, 2006). The problem is compounded by high poverty rate, poor sanitary conditions and inadequacy of clean water. For instance, pastoralism is a normal practice of the inhabitants' that leads to sharing of water with both domestic and wild animals which makes inhabitants ends up using water without proper treatment as it is scarce most of the year. This has led to an increase in diarrhoreal diseases (Omwenga et al., 2009).

Diarrhoea is a killer disease worldwide and unfortunately, it happens to be amongst the symptoms of many other diseases. In most rural communities of developing countries like in the Samburu community of Kenya, diarrhoea poses serious problems particularly to children due to amongst other reasons, lack of adequate sanitation and pipe borne water (Omwenga et al., 2009; Amabeoku,
2009). The disease burden worldwide from water, sanitation and hygiene together has been calculated to be $4 \%$ of all deaths and $5.7 \%$ of the total disease burden. Amongst the many known water borne diseases, diarrhoeal diseases (including cholera) kill more than 1.8 million people every year, mostly children from developing countries (WHO, 2004).

Diarrhoea has long been recognized as one of the most important health problems in developing countries (Snyder and Merson, 1982; Omwenga et al., 2009). It is defined as an increase in the frequency, fluidity or volume of bowel movements and is characterized by increased frequency of bowel sound and movement, wet stool, and abdominal pain. In clinical terms it is used to describe increased liquidity of stool, usually associated with increased stool weight and frequency (Suleiman et al., 2008).

Treatment of diarrhoea is generally non-specific and is usually aimed at reducing the discomfort and inconvenience of frequent bowel movements (Brunton, 1996). To overcome the menace of diarrhoeal diseases in developing countries, the World Health Organization (WHO) has included a programme for the control of diarrhoea, which involves the use of traditional herbal medicine (Snyder and Merson, 1982; Suleiman et al., 2008). 
Medicinal plants are of important therapeutic aid for various ailments including the diarrhoeal diseases. It is estimated that over 20,000 species from several families are useful for these purposes (Kuete et al., 2008). Furthermore, about $80 \%$ of the world population is dependent (wholly or partially) on plant-based drugs (Kuete et al., 2008). Scientific experiments on the antimicrobial properties of plant components were first documented in the late 19th century (Zaika, 1975). The shortcomings of the drugs available today propel the discovery of new pharmacotherapeutic agents in medicinal plants (Kuete et al., 2008). Thus, continuous research should look for antimicrobials that cause fewer negative side effects.

However, there have been numerous reports on the use of traditional plants for the treatment of diarrhoeal diseases (Kuete et al., 2008). In recent years, secondary plant metabolites (phytochemicals) with unknown pharmacological activities have been extensively investigated as a source of medicinal compounds (Kala, 2000). The results obtained have been phenomenal. For instance in one study the ethanolic extracts of Hemidesmus indicus, Coscinium fenestratum, Tephrosia purpurea, Euphorbia hirta, Symplocos racemosa, Curcubito pepo and Eclipta alba were screened against Propionibacterium acnes and Staphylococcus epidermidis. These extracts showed significant activity against the test organisms with $C$. fenestratum showing the strongest inhibitory activity (Kumar et al., 2007). Therefore, medicinal plants are increasingly being projected as a suitable alternative source because of their often multiple targets, minor side effects, low potentials to cause resistance and low costs (Jassim and Naji, 2003).

There are high rates of occurrence of stomach ailments among the Samburu. The diseases gets magnified given the fact that they lack proper medication because of high poverty rates hence prefers the use of local treatment by use of medicinal plants instead of hospitalization. The community believes in medicinal plants first before the patient is hospitalized and in most cases, hospitalization is because of intoxication due to overdoses. In addition, hospitalization comes in when most patients become more serious with the ailments, which may be because of inefficiency of the medicinal plants used probably due to under dosing. It becomes necessary therefore to carry out an evaluation of the most common plants the Samburu use for the treatment of stomach ailments to validate their efficacy.

\section{MATERIALS AND METHODS}

\section{Ethnobotanical survey}

A survey was carried out in Wamba division, Samburu district, Kenya on the major medicinal plants the community uses for the treatment of diarrhoreal diseases. Questionnaires were used to get the plants used by the herbalists and the community in the treatment of the diarrhoreal diseases.

\section{Collection of plant material}

Fresh plant (s) parts that were found to be used by the community for treatment of diarrhoreal diseases after carrying out the survey by use of questionnaires were collected from Samburu-Wamba Conservancies as shown in Figure 1. The taxonomic identities of these plants were confirmed by the senior taxonomist at the Kenyatta University Plant and Microbial Sciences department herbarium where the voucher specimens were deposited.

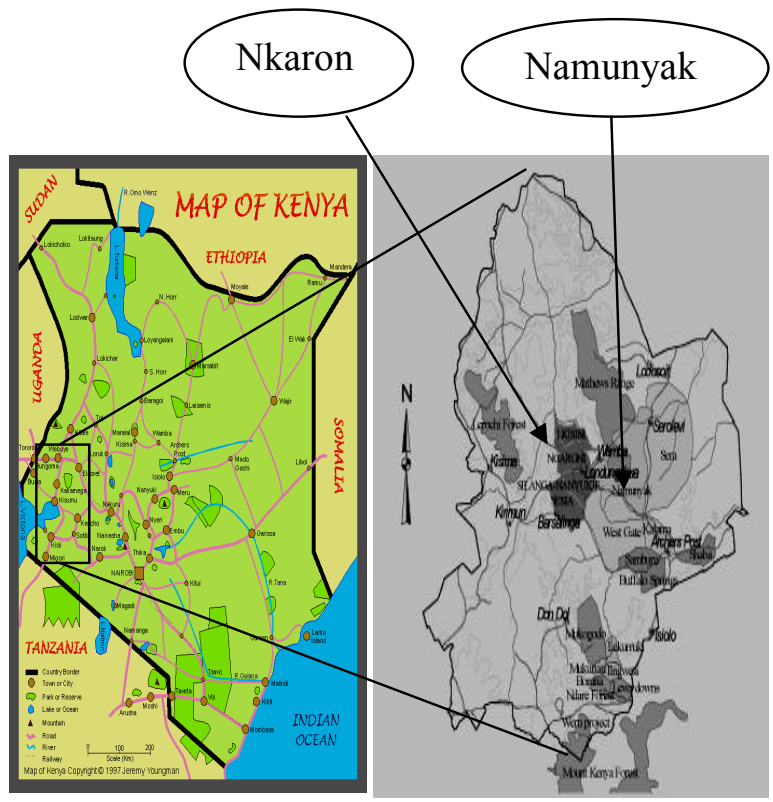

Figure 1: Map of Kenya showing the location of Wamba Division and its conservancies.

\section{Extraction}

Dried, ground plant materials $(50 \mathrm{~g})$ were soaked in 300 $\mathrm{mL}$ of $80 \%$ methanol (MW-32.04) for 12-48 $\mathrm{h}$ with intermittent shaking to allow the active phytochemicals to dislodge in the solvent. The methanol soaked plant extracts were filtered by use of Whatman No. 1 filter paper and the filtrates evaporated until dry weight of each extract was obtained by using the rotary evaporator (VV 2000 Heidolph, Germany) set at $40-50{ }^{\circ} \mathrm{C}$. The extract moisture was reduced to constant weight by additional drying over copper sulphite in a desicator under vacuum.

\section{Antimicrobial screening/bioassay}

\section{Test cultures}

Test cultures were obtained from Kenyatta National Hospital in Nairobi-Kenya, which included Staphylococcus 
aureus (Gram positive cocci) - ATCC 20591, Bacillus subtillis (Gram positive spore forming bacilli) - local isolate, Salmonella typhi (Gram negative rod) - ATCC 2202, Escherichia coli (Gram negative rod) - STD-25922 and Pseudomonas aeruginosa (Gram negative rod) ATCC 25852. All the microorganisms were maintained at $4{ }^{\circ} \mathrm{C}$ on nutrient agar slants. The microorganisms were selected based on their natural differences and cell wall properties, but others $E$. coli and $S$. typhi were chosen because they were identified in Samburu as actual causes of diarrhoea (unpublished data).

\section{Disc diffusion method}

The antimicrobial bioassay was performed by agar disc diffusion method for methanol extracts (Paulo, 2007). The Mueller Hinton agar (Biotec) was prepared following the manufacturers' instructions for purposes of culturing bacteria. A normal saline solution was used to dilute $24 \mathrm{~h}$ bacterial cultures to attain the MacFarland turbidity standard of $0.5 \times 10^{6} \mathrm{CFU} / \mathrm{mL}$. Spread plate method was used to culture $100 \mu \mathrm{L}$ of the microbial suspension that was introduced into the Petri dishes. Then a disc $(6 \mathrm{~mm})$ was saturated with $100 \mu \mathrm{L}$ of the plant extract, allowed to dry and was introduced on the upper layer of the seeded agar plate (Omwenga et al., 2009). The plates were incubated overnight at $37{ }^{\circ} \mathrm{C}$. Microbial growth was determined by measuring the diameter from the end of growth to the disc at one end to the beginning of growth at the other end of inhibition. For each bacterial strain, Amoxicillin $(250 \mu \mathrm{g})$ was used as positive control and methanol as the negative control. The results were again obtained by measuring the zones of inhibition. The experiment was repeated three times and the mean values recorded.

\section{Determination of the Minimum Inhibitory Concentration (MIC) and Minimum Bactericidal Concentration (MBC)}

A micro titre-dilution technique using 96 well micro-plates, (Omwenga et al., 2009) was used to obtain MIC values of the crude extracts against all the test bacteria. Each plant extract was serially diluted to obtain $75 \mathrm{mg} / \mathrm{mL}$, starting from the first well. Similar serial dilutions were performed for Cefrodoxima $(250 \mathrm{mg}$ ), as a positive control. The starting concentration for Cefrodoxima in the first well after the dilution was $75 \mathrm{mg} / \mathrm{mL}$. An equal volume of $50 \mu \mathrm{L}$ fresh bacterial cultures were added to each of the wells. Micro titre-plates were covered and incubated at $37^{\circ} \mathrm{C}$ for $24 \mathrm{~h}$. The MIC values were determined as the lowest concentrations of the extract showing no growth. All the wells where no growth (not turbid) was observed were sub cultured, and the lowest concentration of the plant extracts that did not yield any colony on the solid nutrient medium after sub-culturing and incubating for $12-24 \mathrm{~h}$ was taken as the MBC. All tests were performed in triplicate.

\section{Phytochemical screening}

Qualitative phytochemical analysis of the crude powder of the plants collected was determined by established methods (Omwenga et al., 2009). Tannins presence was determined by dissolving $200 \mathrm{mg}$ plant material in $10 \mathrm{~mL}$ distilled water, and then filtered. Then $2 \mathrm{~mL}$ of the filtrate was taken and $2 \mathrm{~mL}$ iron (III) chloride solution added. A blue-black precipitate indicated the presence of tannins. Alkaloids presence was determined by dissolving $200 \mathrm{mg}$ plant extract in $10 \mathrm{~mL}$ methanol, and was filtered. About 1 $\mathrm{mL}$ of the filtrate was mixed with 6 drops of Wagner's reagent (made by mixing $1.27 \mathrm{~g}$ iodine and $2 \mathrm{~g}$ potassium iodide in $100 \mathrm{~mL}$ of water). A creamish/brownishred/orange precipitate indicated the presence of alkaloids. Saponins presence was determined by the frothing test method (Omwenga et al., 2009) where $0.5 \mathrm{~mL}$ of the filtrate was mixed with $5 \mathrm{~mL}$ distilled water. Frothing persistence indicated presence of saponins. Cardiac glycosides presence was determined by Keller-Kiliani test (Camporese et al., 2003) where $2 \mathrm{~mL}$ of the filtrate was mixed with $1 \mathrm{~mL}$ glacial acetic acid, three drops of Iron (III) chloride and concentrated sulphuric acid. Green-blue colour indicated the presence of cardiac glycosides. Terpenoids presence was determined by taking $5 \mathrm{~mL}$ of the plant extract that was mixed with $2 \mathrm{~mL}$ of chloroform, and $3 \mathrm{~mL}$ of concentrated sulphuric acid was then carefully added to form a layer. A reddish brown coloration of the interface formed indicated the presence of terpenoids. Flavonoids presence was determined by taking $5 \mathrm{~mL}$ of dilute ammonia solution that was added to a portion of the aqueous filtrate of each plant extract followed by addition of concentrated sulphuric acid. A yellow coloration observed in each extract indicated the presence of flavonoids. The yellow coloration disappeared on standing.

\section{Statistical analysis}

The mean zones of inhibition for each test culture were analyzed by one-way analysis of variance (ANOVA) to get the differences among group means. A $p$-value $<0.05$ was considered significant. The means were separated by Turkey's test. The computer software STATISTICA ${ }^{\circledR}$ was employed for the statistical analysis.

\section{RESULTS}

\section{Ethnobotanical survey}

After carrying out the survey, 8 medicinal plants were found to be used by the community in the treatment of various diseases as presented in Table 1. The plants collected incidentally belonged to various families. Various parts were harvested depending on the parts the community prefers to use in the treatment of the various diseases. The bark, roots, leaves and stem were the ones that were harvested, but the part that is used most was found to be the bark of the stem, followed by the roots of the stem and then the leaves/branches. 
Mal. J. Microbiol. Vol 8(2) 2012, pp. 68-74

Table 1: Ethno botanical information of some medicinal plant species traditionally used by Samburu and selected for antimicrobial activity

\begin{tabular}{|c|c|c|c|c|c|c|}
\hline $\begin{array}{l}\text { Botanical } \\
\text { Name }\end{array}$ & $\begin{array}{l}\text { Family } \\
\text { Name }\end{array}$ & $\begin{array}{l}\text { Samburu } \\
\text { Name }\end{array}$ & $\begin{array}{l}\text { Voucher } \\
\text { specimen } \\
\text { number }\end{array}$ & $\begin{array}{l}\text { Part } \\
\text { Used }\end{array}$ & $\begin{array}{l}\text { Diseases } \\
\text { Treated }\end{array}$ & $\begin{array}{l}\text { Area } \\
\text { Found }\end{array}$ \\
\hline $\begin{array}{l}\text { Ocimum suave } \\
\text { Willd. }\end{array}$ & Lamiaceae & Lemuran & DD/SE/17/07 & Bark & $\begin{array}{l}\text { Oral thrush \& } \\
\text { diarrhoea }\end{array}$ & Namunyak \\
\hline $\begin{array}{l}\text { Ormocarpum } \\
\text { trachycarupm } \\
\text { (Taub) Harms }\end{array}$ & Legumiminosae & Lekweita & DD/SE/18/07 & Bark & $\begin{array}{l}\text { Whooping cough } \\
\& \text { diarrhoea }\end{array}$ & Namunyak \\
\hline $\begin{array}{l}\text { Lannea } \\
\text { triphylla } \\
\text { (A.Rich) Engl. }\end{array}$ & Anacardiaceae & Lampurori & DD/SE/19/07 & Bark & $\begin{array}{l}\text { diarrhoea/ } \\
\text { Mumps }\end{array}$ & Nkaroni \\
\hline $\begin{array}{l}\text { Salvodora } \\
\text { persica L. var. } \\
\text { Pérsica }\end{array}$ & Salvadoraceae & Sokotei & DD/SE/20/07 & $\begin{array}{l}\text { Roots/ } \\
\text { leaves }\end{array}$ & Stomach ache & Nkaroni \\
\hline $\begin{array}{l}\text { Solanum } \\
\text { incanum L. }\end{array}$ & Solanaceae & Ltulelei & DD/SE/21/07 & Roots & $\begin{array}{l}\text { Oral thrush and } \\
\text { diarrhoea }\end{array}$ & Namunyak \\
\hline $\begin{array}{l}\text { Teclea } \\
\text { simplicifolia } \\
\text { (Engl.) Verdc. }\end{array}$ & Rutaceae & Lgilai & DD/SE/22/07 & Bark & $\begin{array}{l}\text { Malaria } \\
\text { stomach ache }\end{array}$ & Namunyak \\
\hline $\begin{array}{l}\text { Thylachium } \\
\text { africanum } \\
\text { Lour. }\end{array}$ & Capparaceae & Loimugi & $\mathrm{DD} / \mathrm{SE} / 23 / 07$ & Bark & Diarrhea & Namunyak \\
\hline $\begin{array}{l}\text { Solanum } \\
\text { aculeatissimum } \\
\text { Jacq. }\end{array}$ & Solanaceae & $\begin{array}{l}\text { Ntulelei/ } \\
\text { Ltururai }\end{array}$ & DD/SE/24/07 & Bark & Diarrhea & Nkaroni \\
\hline
\end{tabular}

\section{Disc diffusion}

The antibacterial activities of 8 plant species were assayed in-vitro by agar disc diffusion method against 5 bacterial cultures. Table 2 summarizes the average microbial growth inhibition of the methanol extracts of the screened plant species against the test cultures. From the findings it was observed that all the plants screened had better activity against $P$. aeroginosa than other test isolates with some producing wide zones of inhibition compared to the positive control. Ormocarpum trachycarpum (Taub.) Harms. was the only plant extracts that showed poor activity against most of the tested bacterial cultures except for the $P$. aeroginosa (25.33 $\mathrm{mm}$ ). There was significant difference on the means of the zones of inhibition of the test cultures at $p \leq 0.01$ except in $E$. coli and $B$. subtilis that showed no significant difference even at $p \leq 0.05$. However, the general activity of the plant extracts was average as most of the extracts zones of inhibition were the same as those of the positive control or slightly higher.

The Minimum Inhibitory Concentration (MIC) and Minimum Bactericidal Concentration (MBC)/ Minimum Fungicidal (MFC) results

Most of the extracts produced average MICs and MBCs as shown in Table 3. Lannea triphylla (A. Rich) Engl. Produced the best result among the extracts screened against all the bacterial isolates. Also the extracts of
Thylachium africanum Lour. had good activity on the test cultures producing MICs and MBCs ranging from 18.75 $\mathrm{mg} / \mathrm{mL}$ to $37.5 \mathrm{mg} / \mathrm{mL}$. Most of the extracts expressed a bacteriostatic effect rather than bactericidal effect as they produced different MICs values compared to the MBCs. Also good activity was observed in the Gram negative test isolates as compared to the one observed among the Gram positive bacteria.

\section{Phytochemical screening}

Various phytochemicals were found to be present in the medicinal plants used by the Samburu community as summarized in Table 4. The tested phytochemicals were tannins, saponins, flavonoids, terpenoids, cardiac glycosides and alkaloids. Tannins were found to be the most common phytochemical in the extracts screened especially in Ocimum suave Willd., Solanum incanum L., Teclea simplicifolia (Engl.) Verdc., Thylachium africanum Lour. and Solanum aculeatissimum Jacq. Saponins, cardiac glycosides, alkaloids and flavonoids were also found in a number of the extracts such as Thylachium africanum Lour., and Ormocarpum trachycarpum (Taub.) Harms. as compared to terpenoids. Teclea simplicifolia (Engl.) Verdc., Lannea triphylla, Thylachium africanum Lour. and Solanum incanum L. were found to possess at least all the screened phytochemicals. Solanum aculeatissimum Jacq. was only found to posses tannins among the screened phytochemicals. 
Mal. J. Microbiol. Vol 8(2) 2012, pp. 68-74

Table 2: Average zones of inhibition $(\mathrm{mm})$ of the plant extracts against the bacterial test cultures

\begin{tabular}{lccccc}
\hline \multicolumn{1}{c}{ BOTANICAL NAME } & S. aureus & B. subtilis & S. typhi & E. coli & P. aeroginosa \\
\hline Ocimum suave Willd. & 14 & 14 & 16.66 & 18 & 21 \\
Ormocarpum trachycarpum & 8 & 11 & 8.66 & 11.33 & 25.33 \\
(Taub.) Harms. & 15.33 & 12.66 & 11.66 & 14.33 & 18.66 \\
Lannea triphylla (A.Rich) Engl. & 21.66 & 16.33 & 12.33 & 14.33 & 20 \\
Salvodora persica L. var. persica & 11.33 & 13.66 & 11.33 & 10.33 & 20 \\
Solanum incanum L & 13.66 & 10.66 & 13 & 14.66 & 18.33 \\
Teclea simplicifolia (Engl.) Verdc. & 18.66 & 17.33 & 16.66 & 15 & 23.33 \\
Thylachium africanum Lour. & 17.66 & 17.33 & 12.66 & 15.33 & 20.33 \\
Solanum aculeatissimum Jacq. & 21.33 & 17.17 & 24.17 & 23.58 & 175 \\
Amoxicillin (positive control) & 6 & 6 & 6 & 6 & 6 \\
Negative control & & & & & 6 \\
\hline
\end{tabular}

Table 4: Preliminary phytochemical screening results

\begin{tabular}{|c|c|c|c|c|c|c|}
\hline Botanical plant name & Tannins & Saponins & Flavonoids & Terpenoids & $\begin{array}{l}\text { Cardiac } \\
\text { glycosides }\end{array}$ & $\begin{array}{l}\text { Alkaloids } \\
\text { (Wagner's } \\
\text { test) }\end{array}$ \\
\hline Ocimum suave Willd. & +++ & - & + & + & + & ++ \\
\hline $\begin{array}{l}\text { Ormocarpum trachycarpum } \\
\text { (Taub.) Harms. }\end{array}$ & ++ & + & - & + & ++ & - \\
\hline Lannea triphylla (A. Rich) Engl. & +++ & ++ & ++ & - & - & ++ \\
\hline $\begin{array}{l}\text { Salvodora persica L.var. } \\
\text { pérsica }\end{array}$ & - & - & + & + & + & + \\
\hline Solanum incanum L. & +++ & ++ & + & - & ++ & + \\
\hline $\begin{array}{l}\text { Teclea simplicifolia } \\
\text { (Engl.) Verdc. }\end{array}$ & +++ & + & + & ++ & + & + \\
\hline Thylachium africanum Lour. & +++ & +++ & ++ & - & +++ & +++ \\
\hline Solanum aculeatissimum Jacq. & +++ & - & - & - & - & - \\
\hline
\end{tabular}

\section{DISCUSSION}

Eight anti-diarrhoeal plants from different families used by the Samburu community were identified and harvested from Namunyak and Ngaroni conservancies after carrying out the ethnobotanical survey. It was clear that the community harvests the bark, and roots/ leaves, but the part that is used most was found to be the bark a reason why medicinal plants are becoming scarce. Hence, good conservation measures should be encouraged among communities and traditional healers (Grace, 2002; Omwenga et al., 2009).

Most of the extracts had substantial inhibitory abilities on the growth of the tested cultures. The activity was more of the same in both the Gram positive test cultures and Gram negative a finding that may not be ascribed to the cell wall properties. Among Gram-positive test cultures, $S$. aureus was more susceptible than its counterpart $B$. subtilis. For instance, Salvodora persica L. var. persica (21.66 mm), Thylachium africanum Lour. (18.66 mm) are among the extracts that produced a higher inhibitory activity against the $S$. aureus. This may not be significant as $S$. aureus is affected by most compounds thus further screening of the extracts should be done on the Methicillin Resistant $S$. aureus (MRSA) and the Multi Drug Resistant (MDR) strains. However since the microorganisms can cause food intoxication the findings can still be valid. While for the Gram negative bacterial isolates $P$. aeroginosa was more affected than S. typhi and the $E$. coli. For example Ocimum suave Willd $(21 \mathrm{~mm})$, Ormocarpum trachycarpum (Taub) Harms. (25.33 mm), Thylachium africanum Lour. $(23.33 \mathrm{~mm})$ produced good inhibitory activity against $P$. aeroginosa compared to the positive control Amoxicillin $(17.5 \mathrm{~mm})$. Such results are promising since such a microorganism- $P$. aeroginosa- is hard to be controlled by most antibiotics due to its cell wall properties (Omwenga et al., 2009). This clearly shows that the extracts have a higher diffusion rate and the degree of sensitivity of $P$. aeroginosa to the extracts is higher as compared to that of the positive control. This demonstrates that such extracts can offer alternative 
medicare to diseases caused by $P$. aeroginosa. On the other hand plant extracts might be host specific in their antibacterial activity since zones of inhibition varied for each test culture. The different rates of inhibition could probably be due to the quantity of the phytochemical compounds present in the extracts. However other extracts showed poor activity against some of the test cultures like Ormocarpum trachycarpum (Taub.) Harms. (S. aureus- $8 \mathrm{~mm}$, B. subtilis- $11 \mathrm{~mm}$, S. typhi- $8.66 \mathrm{~mm}$ and $E$. coli- $11.33 \mathrm{~mm}$ ). This can be due to the antagonistic activity of the various phytochemicals that may be present in the extract and such a plant may not offer alternative medicare against such diseases caused by the organisms (Ruttoh et al., 2009).

The extracts screened also produced both bacteriostatic and bactericidal activities against the test cultures with most of them having the bactericidal effect. However, some extracts produced better activities against the Gram negative test cultures than the Gram positive test cultures while others hand had good inhibitory activity against the Gram positive test cultures as shown in table 3 . The presence of a good number of phytochemicals in the plant extracts screened can be a good source of bioactive components with antimicrobial potency, as they can be responsible together with the unscreened ones for the antimicrobial activity of the extracts. Among the phytochemicals screened for tannins were found to be the most abundant followed by the flavonoids and the saponins. These clearly demonstrates the reason as to why the community uses more than one plant to make a concoction for the treatment of a given disease since they can have some additive or synergistic activity against the pathogens of interest (Elgayyar et al., 2000; Ruttoh et al., 2009).

From the work done it shows that phytochemicals have some activity against the diarrhoreal causing pathogens. The activity of such phytochemicals has been found before to possess antimicrobial activity. For instance (Barile et al., 2007) demonstrated that saponins have a significant antibacterial and antifungal activity depending on their concentration. On the other hand the heterocyclic indole compounds which have been found in alkaloids have pharmacological properties like hypotensive activity, anticonvulsant activity, anti-protozoal, anti-diarrhoreal and anti-malarial activities (Mallikharjuna et al., 2007). It is further documented that the presence of some oxindole alkaloids, a flavanone glycoside, narirutin, rosmarinic and isopteropodine in the methanol extracts of Hamelia patens leaves were contributing to the activity of the extract against Escherichia coli and Staphylococcus aureus (Camporese et al., 2003).
Generally, Thylachium africanum Lour. and Lannea triphylla are among the most active extracts that produced significant activity against most of the test culture. These extracts together with others had some substantial amounts of tannins, saponins, flavonoids, terpenoids, alkaloids and cardiac glycosides that have been known to have antimicrobial properties. Thus their activity could be ascribed to the presence of the above phytochemicals and also to the cell wall properties of the tested isolates (Ruttoh et al., 2009). The ability of these extracts to be sensitive to both Gram positive and Gram negative bacteria is a clear indication of their broad spectrum antimicrobial activity.

Therefore, the results confirm that the Samburu medicinal plants have antibacterial potential. The active principle(s) are likely to provide biologically active constituents that will serve as alternatives to presently less effective antimicrobials hence there is need to speculate the mode of action. Therefore, further studies on the in vivo activity, isolation and structural elucidation of the active component(s) and toxicological studies of the plant extracts are recommended. These promissory results open up the possibility of finding new clinically effective antibacterial compounds from these extracts screened.

\section{ACKNOWLEDGEMENT}

The authors are grateful to the Earthwatch Institute for sponsoring the project. Most sincere gratitude also goes to local informants and healers like Margaret Nawamarrian, Samuel Legalgoroule, Benjamin Lekarkaraule, and Lekutuka amongst many who shared their knowledge on the use of medicinal plants with us; as well as Mr. Tom Owuor who assisted in plant collection as an intern student. We are also grateful to Philip Letoile a laboratory technologists at Wamba Catholic Hospital for the enormous assistance he gave to the project. Special thanks finally go to Wamba Catholic Hospital Samburu for accepting and giving us bench space for the laboratory work and to Kenyatta University where finer details of the work were concluded.

\section{REFERENCES}

Amabeoku G.J. (2009). Antidiarrhoeal activity of Geranium incanum Burm. f. (Geraniaceae) leaf aqueous extract in mice. Journal of Ethnopharmacology, 123: 190-193

Barile E, Bonanomi G, Antignani V, Zolfaghari B, Sajjadi S.E, Scala F, and Lanzotti V (2007). Saponins from Allium minutiflorum with antifungal activity. Phytochemistry, 68: 596-603 
Brunton L.L (1996). Agents for control of gastric acidity and treatment of Peptic ulcers. In Goodman and Gilman's the Pharmacological Basis of Therapeutics, 9th ed. McGraw-Hill, New York. Pp 901-915.

Bussmann R.W (2006). Ethnobotany of the Samburu of Mt. Nyiru, South Turkana, Kenya. Journal of Ethnobiology and Ethnomedicine, 2: 35.

Camporese A, Balick MJ, Arvigo R, Esposito R.G, Morsellino N, De Simone F, and Tubaro A (2003). Screening of anti-bacterial activity of medicinal plants from Belize (Central America) Journal of Ethnopharmacology, 87: 103-107

Elgayyar M, Draughon F.A, Golden D.A, and Mount J.N (2000). Antimicrobial activity of Essential oils from plants against selected pathogenic and saprophytic microorganisms. Journal Food Protocol, 64: 10191024

Grace O.M, Prendergast H.D.V, Van Staden J, and Jager A.K (2002). The status of bark in African traditional health care. South African Journal of Botany, 68: 21-30.

Jassim S.A, and Naji M.A (2003). Novel antiviral agents: a medicinal plant perspective. Journal Applied Microbiology, 95: 412-427.

Kala C.P (2000). Status and conservation of rare and endangered medicinal plants in the Indian transHimalya. Biological Conservation, 93: 371-379.

Kuete V, Ngameni B, Fotso Simo C.C, Kengap R, Tankeuc B, Tchaleu Ngadjui J.J.M, Meyer N, and Kuiatea J.R (2008). Antimicrobial activity of the crude extracts and compounds from Ficus chlamydocarpa and Ficus cordata (Moraceae). Journal of Ethnopharmacology, 120:17-24

Kumar G.S , Jayaveera K.N, Ashok Kumar C.K, Umachigi P.S, Vrushabendra Swamy B.M, and Kishore K.D.V (2007). Antimicrobial effects of Indian medicinal plants against acne-inducing bacteria. Tropical Journal of Pharmaceutical Research, 6 (2): 717-723

Mallikharjuna P.B, Rajanna L.N, Seetharam Y.N, and Sharanabasappa G.K (2007). Phytochemical studies of Strychnos potatorum L.f. A medicinal plant. Journal of Chemistry, 4(4): 510-518.

Omwenga E.O, Okemo P.O, Mbugua P.K, and Ogol C.K.P, (2009). Ethnobotanical survey and the antimicrobial evaluation of medicinal plants used by the Samburu community (Kenya) for treatment of diarrhorea. Pharmacognosy magazine, 4 (18): 165176.

Paulo, S (2007). Antimicrobial activity of Syzygium cumini (Myrtaceae) leaves extract. Brazilian Journal of Microbiology, 38: 2-5.

Ruttoh E.K, Tarus P.K, Bii C.C, Machocho A.K, Karimi K.L, and Okemo P.O (2009). Antibacterial activity of Tabernaemontana stapfiana BRITTEN (Apocynaceae) extracts. African Journal of Traditional, complementary and alternative medicine, 6 (2): 186-194.

Snyder J.D, and Merson M.H (1982). The magnitude of the global problem of acute diarrhoeal disease: a review of active surveillance data. Bulletin of the World Health Organization, 60: 604-613.

Suleiman M.M, Dzenda T, and Sani C.A (2008). Antidiarrhoeal activity of the methanol stem-bark extract of Annona senegalensis Pers. (Annonaceae). Journal of Ethnopharmacology, 116: 125-130

World Health Organization-WHO (2004). World Health Report. WHO, Geneva, 120-125.

Zaika L.L (1975). Spices and herbs: their antimicrobial activity and its determination. Journal of Food Safety, 9: 97-118. 